\title{
Keabsahan Keputusan Sirkuler Suatu Perseroan Terbatas Yang Tidak Dinyatakan Dalam Akta Notaris
}

\section{Inka Sukma Faradilla}

Magister Kenotariatan Fakultas Hukum Universitas Islam Indonesia Yogyakarta Indonesia Jln. Cik Di Tiro No. 1 Yogyakarta Indonesia inkasukma2@gmail.com

\begin{tabular}{|c|c|c|}
\hline \multirow[b]{2}{*}{$\begin{array}{l}\text { Key Word: } \\
\text { Circular } \\
\text { limited } \\
\text { company; } \\
\text { deed }\end{array}$} & & Abstract \\
\hline & $\begin{array}{r}\text { decision; } \\
\text { liability } \\
\text { notary }\end{array}$ & $\begin{array}{l}\text { Shareholders of PT. Bumimas Megahprima signed the circular decision in March } \\
\text { 2009. The circular decision included a clause that gave the Board of Directors the } \\
\text { power to convert circular decisions into notarial deeds. While in the reality, the } \\
\text { directors do not carry out their duties to convert the circular decisions in notarial } \\
\text { deeds. This study aims to analyze legal issues related to the validity of circular } \\
\text { decisions that are not solidified into notarial deeds. This research method used is } \\
\text { normative legal research. The result of this study conclude that the circular decision } \\
\text { of PT Bumimas Megah Prima is still valid and legally binding because it is basically } \\
\text { an agreement made by shareholders. }\end{array}$ \\
\hline
\end{tabular}

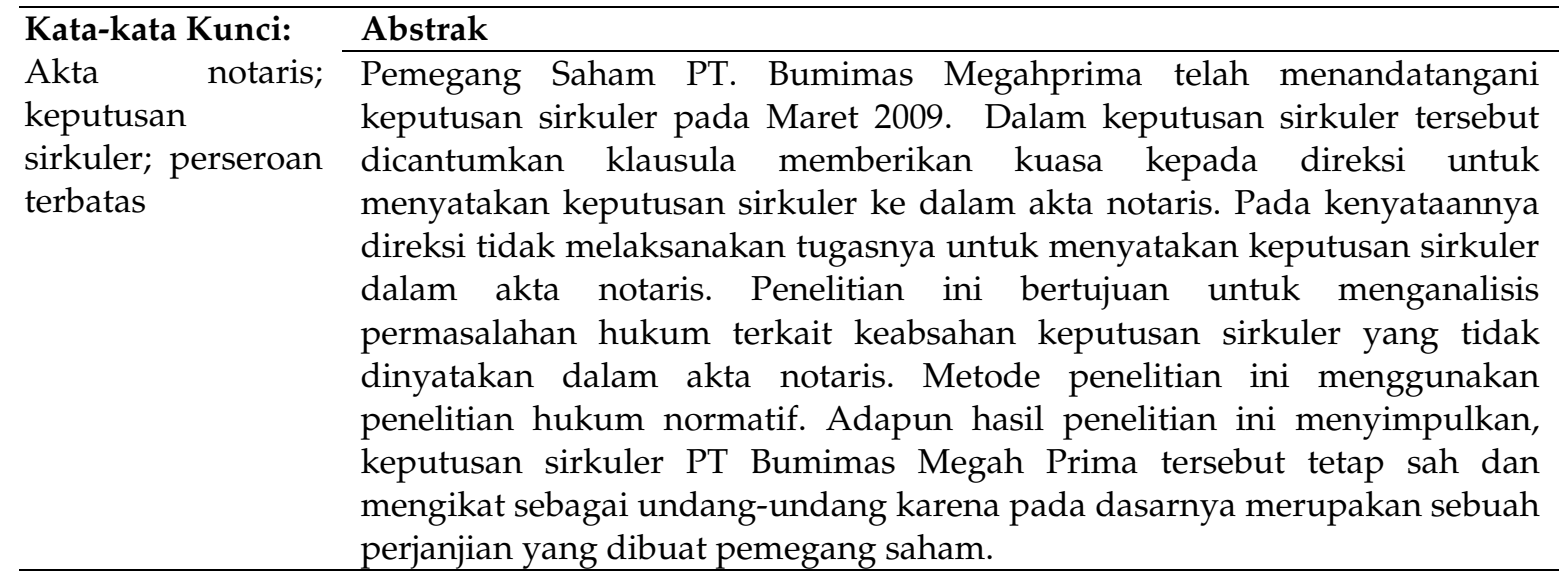

\section{Pendahuluan}

Perseroan terbatas merupakan salah satu sendi utama dalam kehidupan masyarakat modern, karena merupakan salah satu pusat kegiatan manusia untuk memenuhi kehidupan kesehariannya. Sedangkan bagi negara, keberadaan perseroan terbatas merupakan sarana penyalur tenaga kerja dan juga memilki kontribusi yang tidak kecil sebagai sumber pendapatan negara terutama dari sektor pajak. ${ }^{1}$

Perseroan terbatas diatur dalam Undang-Undang Nomor 40 Tahun 2007 tentang Perseroan Terbatas (selanjutnya disebut UUPT). UUPT mengatur secara rinci bentuk dan kegiatan dari perseroan terbatas, serta hak dan kewajiban dari perseroan terbatas. Perseroan terbatas adalah badan hukum yang merupakan persekutuan modal, didirikan berdasarkan perjanjian, melakukan kegiatan usaha dengan modal dasar yang seluruhnya terbagi dalam saham dan memenuhi persyaratan yang ditetapkan dalam UUPT serta

1 Kurniawan, “Tanggung Jawab Direksi Dalam Kepailitan Perseroan Terbatas Berdasarkan UndangUndang Perseroan Terbatas”, Mimbar Hukum, Vol. 24, No. 2, Juni 2012, hlm. 214. 
peraturan pelaksanaannya. ${ }^{2}$ Perseroan terbatas dapat dikatakan merupakan suatu kumpulan saham. ${ }^{3}$

Sebagai suatu kumpulan saham yang berbentuk badan hukum, perseroan terbatas memiliki ciri-ciri sebagai berikut: 4

1. memiliki kekayaan sendiri yang terpisah dari orang-orang yang menjalankan kegiatan dari badan hukum tersebut;

2. memiliki hak dan kewajiban yang terpisah dari hak dan kewajiban orang- orang yang menjalankan kegiatan badan hukum tersebut;

3. memiliki tujuan tertentu;dan

4. berkesinambungan keberadaannya.

Perseroan sebagai badan hukum adalah sama halnya dengan sifat kepribadian manusia yakni mempunyai tujuan, maksud, dan kehendak. ${ }^{5}$ Dalam menjalankan kegiatan usahanya, perseroan terbatas memiliki organ penting sebagaimana diatur dalam Pasal 1 angka 2 UUPT yang mengatur bahwa terdapat tiga organ di dalam perseroan terbatas yaitu Rapat Umum Pemegang Saham (selanjutnya disebut RUPS), direksi, dan komisaris.

Direksi memiliki tugas utama untuk menjalankan dan melaksanakan pengurusan (beheer, administration or management) perseroan atau dapat dikatakan bahwa perseroan diurus, dikelola, dan diatur oleh direksi. ${ }^{6}$ Sedangkan komisaris memiliki fungsi sebagai pengawas kinerja jajaran direksi perusahaan. Komisaris berwenang untuk memeriksa pembukuan, menegur direksi, memberi petunjuk, serta dapat memberhentikan direksi dengan menyelenggarakan RUPS untuk mengambil keputusan apakah direksi akan diberhentikan atau tidak. ${ }^{7}$ Berdasarkan Pasal 1 angka 4 UUPT, RUPS adalah organ perseroan yang mempunyai wewenang yang tidak diberikan kepada direksi atau dewan komisaris dalam batas yang ditentukan dalam UUPT dan/atau anggaran dasar perseroan. Oleh karenanya, RUPS merupakan organ yang mewakili kepentingan seluruh pemegang saham dalam perseroan terbatas.

Dalam UUPT diatur beberapa materi baru, salah satunya adalah pengambilan keputusan di luar RUPS atau yang dikenal dengan circular resolution atau keputusan sirkuler. Keputusan sirkuler belum pernah disebutkan di dalam UUPT 1995 dan hanya disebutkan 1 kali di dalam Penjelasan Pasal 91 UUPT 2007. Istilah ini belum banyak digunakan karena kajian mengenai keputusan sirkuler masih terbatas. ${ }^{8}$ Pengambilan keputusan diluar RUPS (keputusan sirkuler) diatur dalam Pasal 91 UUPT, yang menyatakan:

2 Pasal 1 angka 1 Undang-Undang Nomor 40 Tahun 2007 tentang Perseroan Terbatas.

3 Sentosa Sembiring, Hukum Dagang, Citra Aditya Bakti, Bandung, 2008, hlm. 50.

${ }^{4}$ Binoto Nadapdap, Hukum Perseroan Terbatas, Berdasarkan Undang-Undang No. 40 Tabun 2007, Permata Aksara, Jakarta, 2016, hlm. 6.

5 Agus Budiarto, Kedudukan Hukum dan Tanggung Jawab Pendirian Perseroan Indonesia, Cetakan Kedua, Ghalia Indonesia, Jakarta, 2009, hlm. 27.

${ }^{6}$ M.Yahya Harahap, Hukum Perseroan Terbatas, Cetakan Ketujuh, Sinar Grafika, Jakarta, 2019, hlm. 345.

7 Muhibbuthabary, "Dinamika dan Implementasi Hukum Organisasi Perusahaan dalam Sistem Hukum Indonesia”, Asy-Syari'ah, Volume 17, No. 3, Desember 2015, hlm. 241.

8 Fadlyna Ulfa Faisal, et. al., "Pelaksanaan Circular Resolution pada Perseroan Terbatas", dalam http://pasca.unhas.ac.id/jurnal/files/86802e6ad7e7c1fb.pdf, akses 20 Juni 2020. 
"Pemegang saham dapat juga mengambil keputusan yang mengikat di luar RUPS dengan syarat semua pemegang saham dengan hak suara menyetujui secara tertulis dengan menandatangani usul yang bersangkutan."

Selanjutnya dalam Penjelasan Pasal 91 UUPT disebutkan:

"Yang dimaksud dengan "pengambilan keputusan di luar RUPS" dalam praktik dikenal dengan usul keputusan yang diedarkan (circular resolution). Pengambilan keputusan seperti ini dilakukan tanpa diadakan RUPS secara fisik, tetapi keputusan diambil dengan cara mengirimkan dokumen secara tertulis usul yang akan diputuskan kepada semua pemegang saham dan usul tersebut disetujui secara tertulis oleh seluruh pemegang saham. Yang dimaksud dengan "keputusan yang mengikat" adalah keputusan yang mempunyai kekuatan hukum yang sama dengan keputusan RUPS."

Berdasarkan kutipan di atas, bahwa pengambilan keputusan pemegang saham di luar RUPS dilakukan dengan cara mengedarkan usulan tertulis kepada para pemegang saham serta memiliki kekuatan mengikat sebagaimana keputusan RUPS, dengan syarat bahwa seluruh pemegang saham memberikan persetujuan dan menandatangani keputusan sirkuler secara bulat tanpa terkecuali.

Dalam pembuatan keputusan sirkuler ini juga dapat menimbulkan permasalahan, seperti kasus yang diputus oleh Mahkamag Agung RI lewat Putusan Mahkamah Agung RI Nomor 1320K/PDT/2016 tertanggal 16 Agustus 2016 jo. Putusan Pengadilan Tinggi DKI Jakarta Nomor 493/PDT/2015/PT.DKI tertanggal 13 Oktober 2015 jo. Putusan Pengadilan Negeri Jakarta Selatan Nomor 193/Pdt.G/2014/PN.Jkt.Sel tertanggal 14 Januari 2015, dalam perkara antara PT. Duta Jakarta Sejahtera (selaku penggugat/tergugat rekonpensi) melawan PT. Intitacon Lestari (tergugat I/penggugat rekonpensi), Sdr. Djajang Tanuwidjaja (tergugat II), PT Bumimas Megahprima (turut tergugat I), Sdr. Haryanto, SH (Notaris/turut tergugat II), Sdr. Ilmiawan Dektrit Supatmo, SH., MH (Notaris/turut tergugat III), Kementrian Hukum dan Hak Asasi Manusia RI (Turut Tergugat IV). Kronologi dimulai pada bulan Maret 2009, seluruh pemegang saham PT Bumimas Megahprima telah menandatangani keputusan para pemegang saham di luar RUPS (Keputusan Sirkuler) yang memutuskan dan menyetujui usulan-usulan sebagai berikut: ${ }^{9}$

a. Perubahan seluruh Anggaran Dasar PT;

b. Pemberhentian seluruh anggota Direksi dan Komisaris PT Bumimas Megahprima;

c. Menyatakan kembali susunan Pemegang Saham PT Bumimas Megahprima;

d. Terhitung sejak tanggal diterbitkannya surat persetujuan Anggaran Dasar oleh Menteri Hukum dan Hak Asasi Manusia RI atas perubahan seluruh Anggaran Dasar sebagaimana tersebut di atas, mengangkat kembali anggota Direksi dan Komisaris untuk jangka waktu 5 (lima) tahun setelah tanggal pengangkatannya;

e. Memberi kuasa kepada Direksi Perseroan dengan hak substitusi untuk menandatangani akta-akta yang diperlukan sehubungan dengan keputusan ini dan ketentuan yang disyaratkan oleh instansi yang berwenang.

9 Putusan Mahkamah Agung Republik Indonesia pada tingkat Kasasi, dalam perkara PT Duta Jakarta Sejahtera v. Djadjang Tanuwidjaja, Nomor 1320K/PDT/2016, hlm. 04. 
Tergugat II selaku direktur menolak untuk menuangkan keputusan sirkuler tersebut kedalam akta notaris dan tentunya tidak dilaporkan kepada Kementerian Hukum dan Hak Asasi Manusia (selanjutnya disebut Kemenkumham) dengan alasan bahwa yang bersangkutan belum membaca isi akta pernyataan keputusan para pemegang saham.

Pada kasus di atas, Mahkamah Agung (selanjutnya disebut MA) memutuskan bahwa keputusan sirkuler Maret 2009 dinyatakan sah dan dapat dituangkan ke dalam akta notaris tentang keputusan sirkuler dalam rangka persetujuan perubahan Anggaran Dasar dan pemberitahuan perubahan tentang data Tergugat I, serta menyatakan batal dan tidak mengikat segala keputusan para pemegang saham yang diterbitkan setelah Maret 2009.

Berkenaan dengan keputusan sirkuler yang tidak dinyatakan dalam akta notaris, maka memunculkan permasalahan tentang keabsahan keputusan sirkuler yang tidak dinyatakan dalam akta notaris.

\section{Rumusan Masalah}

Berdasarkan uraian latar belakang di atas, permasalahan dalam penelitian ini yakni, bagaimana keabsahan keputusan sirkuler (circular resolution) yang tidak dinyatakan dalam akta notaris?

\section{Tujuan Penelitian}

Tujuan dalam penelitian ini yakni, untuk menganalisis keabsahan keputusan sirkuler (circular resolution) terkait perubahan anggaran dasar perseroan yang tidak dinyatakan dalam akta notaris.

\section{Metode Penelitian}

Penelitian ini merupakan penelitian hukum normatif atau doktrinal, ${ }^{10}$ yaitu dengan meneliti pada data sekunder bidang hukum yang ada sebagai data kepustakaan dengan menggunakan metode berpikir deduktif. Pendekatan yang dipergunakan oleh penulis adalah pendekatan perundang-undangan (statue approach), pendekatan konseptual (conceptual approach), serta tidak menutup kemungkinan dipergunakan pendekatan kasus (case approach).

Teknik pengumpulan bahan hukum dengan studi kepustakaan yaitu menelusuri bahan-bahan hukum yang dilakukan dengan membaca, melihat, maupun melalui media internet. ${ }^{11}$ Sumber hukum terdiri dari, pertama, bahan hukum primer antara lain, (1) Undang-Undang Nomor 40 Tahun 2007 tentang Perseroan Terbatas; (2) Undang-Undang Nomor 30 Tahun 2004 tentang Jabatan Notaris; (3) Kitab Undang-Undang Hukum Perdata [Burgerlijke Wetboek]; (4) Peraturan Menteri Hukum Dan Hak Asasi Manusia Nomor 4 Tahun 2014 tentang Tata Cara Pengajuan Permohonan Pengesahan Badan Hukum dan Persetujuan Perubahan Anggaran Dasar serta Penyampaian Pemberitahuan

${ }^{10}$ Muslan Abdurrahman, Sosiologi dan Metode Penelitian Hukum, UMM Press, Malang, 2009, hlm. 127.

11 Beni Ahmad Saebani, Metode Penelitian Hukum, Pustaka Setia, Bandung, 2008, hlm. 57. 
Perubahan Anggaran Dasar dan Perubahan Data Perseroan Terbatas; dan (5) Putusan Mahkamah Agung Nomor 1320K/Pdt/2016 jo. Putusan Pengadilan Tinggi Nomor 493/PDT/2015/PT.DKI. jo. Putusan Pengadilan Negeri Jakarta Selatan Nomor 193/Pdt.G/2014/PN.Jkt.Sel.

Kedua, bahan hukum sekunder yakni, berbagai buku, jurnal hukum dan sumbersumber dari internet yang membahas mengenai keputusan sirkuler. Ketiga, bahan hukum tersier yakni adalah Kamus Hukum dan Black's Law Dictionary. Analisis data dilakukan secara kualitatif. Data penelitian dianalisis sesuai dengan permasalahan dan berdasarkan kerangka teori yang ada dan dituliskan secara logis dan sistematis. Analisis dilakukan dengan inventarisasi ketentuan-ketentuan dalam peraturan perundang-undangan. Oleh kemudian, dikomparasikan dengan teori-teori yang relevan.

\section{Hasil Penelitian dan Pembahasan}

\section{Keabsahan Keputusan Sirkuler (Circular Resolution) yang Tidak Dinyatakan dalam Akta Notaris}

Keputusan Sirkuler (Circular Resolution) dikatakan sah menurut hukum apabila semua pemegang saham dengan hak suara dalam perseroan menyetujui secara tertulis dengan menandatangani usul keputusan yang bersangkutan. Tidak boleh ada satupun pemegang saham yang tidak setuju dengan usul keputusan yang bersangkutan, karena jika hal tersebut terjadi maka mengakibatkan keputusan sirkuler (circular resolution) menjadi tidak sah.

Pasal 91 UUPT telah memberikan ketentuan bahwa pemegang saham dapat juga mengambil keputusan yang mengikat diluar RUPS dengan syarat semua pemegang saham dengan hak suara menyetujui secara tertulis dengan menandantangani usul yang bersangkutan. Demikian pula dalam Penjelasan Pasal 91 UUPT yang menjelaskan bahwa yang dimaksud dengan pengambilan keputusan diluar RUPS dalam praktik dikenal dengan usul keputusan yang diedarkan (circular resolution). Pengambilan keputusan seperti ini dilakukan tanpa RUPS secara fisik, tetapi keputusan ini diambil dengan cara mengirimkan secara tertulis usul yang akan diputuskan kepada semua pemegang saham dan persetujuan atas usul tersebut diberikan secara tertulis oleh seluruh pemegang saham. Keputusan Sirkuker (circular resolution) menjadi keputusan yang mengikat di luar RUPS, maksudnya adalah keputusan yang mempunyai kekuatan hukum yang sama dengan keputusan RUPS.

Dalam prakteknya setiap usul keputusan sirkuler (circular resolution) tersebut biasanya terdapat klausul mengenai pemberian kuasa kepada perseroan dalam hal ini direksi untuk selanjutnya menuangkan keputusan sirkuler tersebut ke dalam akta otentik yang dibuat dihadapan notaris. Sebagaimana dalam Keputusan Sirkuler PT Bumimas Megahprima yang menyebutkan:12

"Menimbang, bahwa didalam Keputusan Sirkuler yang dibuat oleh Penggugat, Tergugat I dan Penggugat telah dicantumkan pula klausula memberi kuasa kepada Direksi Perseoran dengan kuasa substitusi untuk menandatangani akta-akta yang

12 Putusan Pengadilan Negeri Jakarta Selatan pada tingkat Pertama dalam Perkara PT Duta Jakarta Sejahtera v. Djadjang Tanuwidjaja, Nomor 193/Pdt.G/2014/PN.Jkt.Sel., hlm. 109. 
diperlukan sehubungan dengan keputusan rapat dan ketentuan yang disyaratkan oleh instansi yang berwenang".

Keputusan sirkuler (circular resolution) selanjutnya oleh direksi atau yang diberikan kuasa berdasarkan keputusan sirkuler, dimuat atau dinyatakan dalam akta notaris tentunya mendasarkan pada Pasal 21 ayat (1), (2), (3) dan (4) UUPT. Dalam keputusan sirkuler bisa saja melakukan perubahan anggaran dasar yang harus mendapatkan persetujuan menteri dan/atau melakukan perubahan anggaran dasar yang tidak perlu mendapat persetujuan menteri tetapi cukup diberitahukan kepada menteri.

Di luar dari apa yang tertuang dalam Pasal 21 ayat (2) UUPT, menurut Pasal 21 ayat (3) UUPT cukup diberitahukan kepada menteri, maka oleh menteri akan diterbitkan surat yang menyatakan bahwa pemberitahuan telah diterima dan telah dicatat dalam Daftar Perseroan dalam Sistem Administrasi Badan Hukum (SABH) yang ada di kementerian. Perubahan tersebut dibuat dengan akta notaris dalam bahasa Indonesia, paling lambat 30 hari terhitung sejak tanggal keputusan rapat.

Perubahan anggaran dasar perseroan yang diputuskan dalam keputusan sirkuler yang dituangkan ke dalam akta notaris yang selanjutnya oleh notaris dilaporkan kepada Menteri Hukum dan Hak Asasi Manusia Republik Indonesia (selanjutnya disebut Menkumham RI) untuk mendapatkan persetujuan atau perubahan anggaran perseroan selain itu yang sekedar cukup diberitahukan kepada Menkumham RI, tentunya agar keputusan sirkuler tersebut dapat mengikat kepada pihak ketiga.

Putusan yang penulis teliti telah memberikan pertimbangan hukum berkenaan dengan keabsahan keputusan sirkuler terkait perubahan anggaran perseroan yang tidak dituangkan dalam akta notaris. Kasus ini bermula ketika PT Bumimas Megaprima yang didirikan pada 8 Agustus 1990, berdasarkan RUPS tertanggal 30 April 2002, memiliki susunan pemegang saham sebagai pada tabel berikut:

Tabel.1

Susunan Pemegang Saham PT. Bumimas Megaprima RUPS 30 April 2002

\begin{tabular}{lllll}
\hline \multirow{2}{*}{ No } & \multicolumn{1}{c}{ Pemegang Saham } & Jumlah Saham & \multirow{2}{*}{ Nilai Nominal (Rp) } & Prosentase (\%) \\
\hline 1 & Ir. Djajang Tanuwidjaja & 114.750 & 114.750 .000 & 11,475 \\
2 & PT Duta Jakarta Sejahtera & 395.250 & 395.250 .000 & 39,525 \\
3 & PT Intitacon Lestari & 490.000 & 490.000 .000 & 49 \\
\hline
\end{tabular}

Pada Maret 2009, seluruh pemegang saham tersebut diatas telah menandatangani keputusan rapat pemegang saham di luar RUPS PT Bumimas Megahprima (selanjutnya disebut Keputusan Sirkuler Maret 2009) yang memutuskan dan menyetujui, antara lain usulan-usulan sebagai berikut:13

a. Perubahan seluruh Anggaran Dasar PT. Bumimas Megah Prima sesuai UndangUndang RI No. 40 Tahun 2007 Tentang Perseroan Terbatas.

b. Pemberhentian seluruh anggota Direksi dan Komisaris PT Bumimas Megahprima dengan memberikan pelunasan dan pembebasan tanggung jawab (acquit et

13 Putusan Pengadilan Negeri Jakarta Selatan pada tingkat Pertama dalam Perkara PT Duta Jakarta Sejahtera v. Djadjang Tanuwidjaja, Nomor 193/Pdt.G/2014/PN.Jkt.Sel., hlm. 5-7. 
decharge) atas semua tindakan pengurusan dan pengawasan yang telah mereka lakukan selama menjabat sepanjang tindakan tersebut sesuai dengan Anggaran Dasar dan tercermin dalam laporan keuangan Perseroan, dan pengangkatan anggota Direksi dan Komisaris PT Bumimas Megahprima terhitung sejak Keputusan Pemegang Saham ini berlaku efektif, sampai dengan 1 hari sebelum diterbitkannya surat persetujuan perubahan Anggaran Dasar oleh Menteri Hukum dan Hak Asasi Manusia, yaitu : Direktur Utama Djajang Tanuwidjaja, Direktur Hermawan Wijaya, Direktur Tonny Tanuwijaya, Komisaris Utama Harry Budi Hartanto, Komisaris Efendi Soemito;

c. Menyatakan kembali susunan Pemegang Saham PT Bumimas Megahprima;

d. Terhitung sejak tanggal diterbitkannya surat persetujuan Anggaran Dasar oleh Menteri Hukum dan Hak Asasi Manusia RI atas perubahan seluruh Anggaran Dasar sebagaimana tersebut di atas, mengangkat kembali anggota Direksi dan Komisaris untuk jangka waktu 5 tahun setelah tanggal pengangkatannya;

e. Memberi kuasa kepada Direksi Perseroan dengan hak substitusi untuk menandatangani akta-akta yang diperlukan sehubungan dengan keputusan ini dan ketentuan yang disyaratkan oleh instansi yang berwenang.

Bahwa jika melihat dari isi keputusan sirkuler (circular resolution) tersebut diatas berisikan penyesuaian perubahan seluruh anggaran dasar perseroan dari UndangUndang Nomor 1 Tahun 1995 tentang Perseroan Terbatas kedalam Undang-Undang Nomor 40 Tahun 2007 tentang Perseoran Terbatas. Dari putusan perkara a quo yang diteliti tidak tergambar dengan jelas materi perubahaan anggaran dasar perseroan PT Bumimas Megahprima apakah mencakup perubahan anggaran sebagaimana ketentuan Pasal 21 ayat (2) huruf a s/d huruf g yang harus mendapat persetujuan menteri atau cukup diberitahukan kepada menteri. Dalam putusan perkara a quo yang menjadi persoalan adanya keputusan sirkuler berkenaan perubahan anggaran dasar perseroan mengenai kuorum RUPS / RUPSLB.

Oleh karenanya menurut Penulis, jika memang keputusan sirkuler (circular resolution) PT Bumimas Megahprima terkandung perubahan anggaran dasar perseroan sebagaimana Pasal 21 ayat (2) UU PT maka perlu mengajukan permohonan persetujuan kepada Menkumham RI, namun jika ternyata keputusan sirkuler PT Bumimas Megahprima berisikan perubahan anggaran dasar perseroan selain sebagaimana dimaksud Pasal 21 ayat (2) UU PT maka cukup diberitahukan kepada menteri.

Permasalahan terkait keputusan sirkuler itu muncul ketika direksi perseroan yang diberikan kuasa sebagaimana dalam keputusan sirkuler untuk mengaktakan keputusan sirkuler dihadapan notaris pada 06 Maret 2009 ternyata menolak untuk membuat akta pernyataan keputusan para pemegang saham terkait Keputusan Sirkuler Maret 2009 tersebut dengan alasan bahwa yang bersangkutan belum membaca akta pernyataan keputusan para pemegang saham. Padahal direksi perseroan dalam hal ini direktur utama Djajang Tanuwidjaja juga merupakan salah satu pemegang saham yang telah setuju untuk mengikatkan diri bersama-sama para pemegang saham yang lain yakni PT Duta Jakarta Sejahtera dan PT Intitacon Lestari dalam keputusan sirkuler dengan menandatangani usul keputusan bersangkutan beserta memberikan paraf disetiap lampiran usul keputusan sirkuler tersebut. Pada akhirnya hal tersebut berujung pada 
diajukannya gugatan oleh PT Duta Jakarta Sejahtera sebagai salah satu pemegang saham PT Bumimas Megahprima kepada Pengadilan Negeri Jakarta Selatan.

Disatu sisi Penggugat beranggapan Keputusan Sirkuler (circular resolution) PT Bumimas Megah Prima yang telah dibuat dan disepakati adalah sah dan mengikat kepada para pemegang saham, namun disisi lain Tergugat I dan Tergugat II beranggapan keputusan sirkuler tersebut tidak sah dan tidak berlaku, mengingat keputusan sirkuler tersebut belum dinyatakan dalam akta notaris dan juga belum didaftar atau belum diajukan permohonan persetujuan atau pemberitahuan kepada menteri.

Dalam putusan majelis hakim telah memberikan pertimbangan hukum berkenaan dengan apakah keputusan para pemegang saham PT Bumimas Megahprima di luar Keputusan Sirkuler RUPS Maret 2009 yang tidak dinyatakan dalam akta notaris sah atau tidak sah menurut hukum. Dalam putusan Pengadilan Negeri Jakarta Selatan yang dikuatkan oleh Putusan PT DKI Jakarta dan Putusan MA RI, telah memberikan pertimbangan hukum sebagai berikut :14

"Menimbang sebagaimana fakta yang diperoleh dipersidangan ternyata Keputusan Sirkuler tersebut tidak di aktakan oleh Direksi Turut Tergugat I dan Perubahan Anggaran Dasar tidak didaftarkan ke Kementerian Hukum dan Hak Asasi Manusia; Menimbang, bahwa walaupun Keputusan Sirkuler tersebut belum diakatkan di Notaris dan Perubahan Anggaran Dasarnya belum didaftarkan di Kementerian Hukum dan HAM oleh karena Keputusan Sirkuler tersebut sifatnya adalah perjanjian atau kesepakatan yang dibuat oleh Tergugat I, Tergugat II dan Penggugat, maka sebagaimana ketentuan Pasal 1338 KUH Perdata, Keputusan Sirkuler tersebut mengikat dan berlaku sebagai Undang-Undang bagi Tergugat I, Tergugat II dan Penggugat tersebut dan apabila Perubahan Anggaran Dasarnya tersebut didaftarkan di Kementerian Hukum dan Hak Asasi Manusia maka hal tersebut menyebabkan berlaku juga kepada Pihak Ketiga;

Menimbang, bahwa oleh karena Keputusan Sirkuler tersebut telah mengikat dan berlaku sebagai Undang-Undang bagi Tergugat I, Tergugat II dan Penggugat maka apabila Tergugat I dan Tergugat II ingin merobah kembali isi Keputusan Sirkuler tersebut termasuk untuk merobah kembali Kourum kehadiran dan Kourum sahnya pengambilan keputusan dalam RUPS/RUPS LB ataupun Kourum terhadap Perubahn Anggaran Dasar yang telah terlanjut disetujui melalui Keputusan Sirkuler haruslah dengan Kourum kehadiran dan Kourum untuk sahnya pengambilan keputusan yang telah disetujui dan disepakati melalui Keputusan Sirkuler tersebut sampai di batalkannya kembali Kourum tersebut melalui RUPS/RUPSLB atau Keputusan Sirkuler yang baru;"

Pertimbangan hukum majelis hakim tersebut diatas menurut penulis menunjukkan meskipun keputusan sirkuler tersebut tidak dinyatakan dalam akta notaris dan belum didaftarkan kepada Menkumham RI tetap dinyatakan sah dan mengikat bagi para pemegang saham yang telah menyetujui dan menandatangani keputusan sirkuler yang dibuat. Adapun dasar untuk menyatakan keputusan sirkuler tersebut sah karena keputusan sirkuler sifatnya merupakan perjanjian atau kesepakatan yang dibuat oleh Tergugat I, Tergugat II, dan penggugat didasarkan pada ketentuan Pasal $1320 \mathrm{KUH}$

14 Putusan Pengadilan Negeri Jakarta Selatan pada tingkat Pertama dalam Perkara PT Duta Jakarta Sejahtera v. Djadjang Tanuwidjaja, Nomor 193/Pdt.G/2014/PN.Jkt.Sel., hlm. 109-110. 
Perdata dan Pasal 1338 KUH Perdata yang mengikat dan berlaku sebagai undangundang bagi yang membuatnya.

Perseroan terbatas sebagaimana dalam ketentuan Pasal 1 angka 1 UUPT disebutkan bahwa perseroan terbatas adalah badan hukum yang merupakan persekutuan modal, didirikan berdasarkan perjanjian, melakukan kegiatan usaha dengan modal yang seluruhnya terbagi dalam saham dan memenuhi persyaratan yang ditetapkasn dalam undang-undang ini serta peraturan pelaksanaannya, maka definisi perseoran terbatas tersebut dapat dikatakan berdirinya perseroan terbatas sebagai badan hukum didasarkan adanya "Perjanjian" diantara para pemegang saham. Dengan demikian berdirinya suatu perseroan terbatas dapat dikatakan sebagai akibat hukum yang lahir dari adanya hubungan kesepakatan (kontraktual) atau perjanjian diantara para pemegang saham sebagai pihak-pihak yang mengikatkan diri untuk mendirikan suatu badan hukum yang bernama perseroan terbatas.

Perjanjian dalam mendirikan perseroan terbatas haruslah tunduk pada dan memenuhi ketentuan hukum perjanjian yang diatur dalam KUH Perdata Buku III, Bab II, Bagian I tentang Ketentuan Umum Perjanjian (Pasal 1313-1319 KUH Perdata) dan bagian tentang Syarat-syarat Sahnya Perjanjian Pasal 1320-1337 KUH Perdata, serta Bagian Ketiga tentang Akibat Perjanjian Pasal 1338-1341 KUH Perdata. Pasal 1313 KUH Perdata sendiri memberikan definisi tentang perjanjian sebagai suatu perbuatan dengan mana satu orang atau lebih mengikatkan dirinya terhadap satu orang lainnya atau lebih. Ketentuan Pasal 1313 KUH Perdata tersebut sejalan dengan Pasal 7 ayat (1) UUPT yang mengatur bahwa perseroan terbatas didirikan oleh 2 orang atau lebih. Penjelasan Pasal 7 ayat (1) UU PT juga menegaskan kembali bahwa pada dasarnya sebagai badan hukum, perseroan terbatas didirikan berdasarkan perjanjian, dikarenakan mempunyai lebih dari 1 orang pemegang saham.

Menurut penulis karena pendirian perseroan terbatas (anggaran dasar termasuk perubahan-perubahannya) yang didasarkan adanya perjanjian maka hal tersebut mengikat sebagai undang-undang bagi para pendirinya atau para pemegang sahamnya. Oleh karena itu, untuk selanjutnya keputusan sirkuler dapat dinyatakan sah sebagai suatu perjanjian dan mengikat para pihak yang membuatnya atau para pemegang saham sebagai undang-undang tentunya harus dilihat apakah keputusan sirkuler tersebut telah memenuhi syarat sahnya suatu perjanjian sebagaimana diatur dalam Pasal $1320 \mathrm{KUH}$ Perdata. Dalam perkara PT Bumimas Megahprima tersebut, menurut penulis telah memenuhi seluruh syarat sahnya suatu perjanjian sebagaimana dimaksud dalam Pasal 1320 KUH Perdata, Pasal 1 angka 1 UUPT, Pasal 7 ayat (1) dan Penjelasan Pasal 7 ayat (1) UUPT dan Pasal 91 UUPT. Akibat hukum perjanjian yang sah dalam hal ini keputusan sirkuler yang sah, maka sesuai ketentuan Pasal 1338 KUH Perdata keputusan sirkuler berlaku sebagai undang-undang bagi para pembuatnya (para pemegang saham).

Oleh karena itu, apabila para pemegang saham PT Bumimas Megahprima ingin mengadakan RUPS atau RUPSLB atau membuat keputusan sirkuler kembali, haruslah didasarkan pada keputusan sirkuler yang telah dibuat tersebut meskipun pada faktanya Keputusan Sirkuler PT Bumimas Megahprima Maret 2009 belum dituangkan dalam akta notaris dan perubahan anggaran dasar tidak didaftarkan ke Kemenkumham RI oleh direksi yang diberikan kuasa. 
Meskipun keputusan sirkuler PT Bumimas Megahprima tersebut tidak dinyatakan dalam akta notaris, keputusan sirkuler PT Bumimas Megahprima tetap sah dan mengikat para pemegang saham PT Bumimas Megahprima. Pasal 21 ayat (4) UUPT telah menentukan bahwa terhadap perubahan anggaran dasar sebagaimana dimaksud dalam ayat (2) dan ayat (3) dimuat atau dinyatakan dalam akta notaris dalam Bahasa Indonesia. Sehingga fungsi akta notaris yang memuat perubahan anggaran dasar untuk keperluan permohonan persetujuan atau pemberitahuan perubahan anggaran dasar kepada Menkumham RI, agar keputusan sirkuler tersebut juga berlaku kepada pihak ketiga. Adapun konsekuensinya apabila keputusan sirkuler tersebut tidak dituangkan dalam akta notaris maka keputusan sirkuler tersebut hanya mengikat para pemegang saham dan tidak mengikat kepada pihak ketiga.

\section{Penutup}

Berdasarkan hasil penelitian dan pembahasan di atas, kesimpulan dalam penelitian ini yakni, keputusan sirkuler yang dibuat oleh para pemegang saham berkenaan dengan perubahan anggaran dasar perseroan yang tidak dimuat dalam akta notaris dapat dikatakan sah dan mengikat sebagai undang-undang bagi para pembuatnya sebagaimana yang terdapat dalam Pasal 1338 KUHPerdata, karena keputusan sirkuler pada dasarnya merupakan sebuah perjanjian atau kesepakatan yang dibuat oleh para pemegang saham. Keabsahan suatu keputusan sirkuler dikatakan sah sepanjang semua pemegang saham dengan hak suara menyetujui secara tertulis dan menandatangani usul keputusan sirkuler dan memenuhi syarat-syarat sahnya suatu perjanjian sebagaimana dimaksud dalam Pasal 1320 KUHPerdata. Akibat hukum perjanjian yang sah dalam hal ini keputusan sirkuler yang sah, maka sesuai ketentuan Pasal 1338 KUHPerdata berlaku sebagai undang-undang bagi para pembuatnya (para pemegang saham). Meskipun Keputusan Sirkuler PT Bumimas Megah Prima yang berisikan perubahan anggaran dasar belum dinyatakan dalam akta notaris dan belum didaftarkan kepada Menteri Hukum dan HAM RI tetap dinyatakan sah dan mengikat sebagai undang-undang bagi pembuatnya yakni para pemegang saham, proses pendaftaran perubahan anggaran dasar persero baik yang memerlukan persetujuan menteri atau perubahaan anggaran dasar yang cukup sekedar diberitahukan kepada menteri, terkait dengan keberlakuannya kepada pihak ketiga.

Berdasarkan kesimpulan di atas, saran dalam penelitian ini yakni, perlu adanya pemahaman bahwa keputusan sirkuler yang telah dibuat oleh para pemegang saham telah mengikat dan berlaku sebagai undang-undang bagi para pemegang saham, termasuk direksi yang telah diberikan kuasa untuk mengaktakan keputusan sirkuler dalam akta notaris tentunya harus menjalankan keputusan sirkuler tersebut. Bilamana ternyata para pemegang saham ingin merubah kembali isi keputusan sirkuler tersebut, maka tentunya untuk merubahnya haruslah didasarkan kepada keputusan sirkuler yang telah disetujui dan disepakati tersebut.

\section{Daftar Pustaka}

\section{Buku}

Abdurrahman, Muslan, Sosiologi dan Metode Penelitian Hukum, UMM Press, Malang, 2009. 
Ahmad Saebani, Beni, Metode Penelitian Hukum, Pustaka Setia, Bandung, 2008.

Budiarto, Agus, Kedudukan Hukum dan Tanggung Jawab Pendirian Perseroan Indonesia, Cetakan Kedua, Ghalia Indonesia, Jakarta, 2009.

Harahap, M. Yahya, Hukum Perseroan Terbatas, Cetakan Ketujuh, Jakarta, Sinar Grafika, 2019.

Nadapdap, Binoto, Hukum Perseroan Terbatas, Berdasarkan Undang-Undang No. 40 Tahun 2007, Jala Permata Aksara, Jakarta, 2016.

Sembiring, Sentosa, Hukum Dagang, Citra Aditya Bakti, Bandung, 2008.

Jurnal

Kurniawan, "Tanggung Jawab Direksi Dalam Kepailitan PerseroanTerbatas Berdasarkan Undang-Undang Perseroan Terbatas", Mimbar Hukum, Volume 24, Nomor 2, Juni 2012.

Muhibbuthabary, "Dinamika dan Implementasi Hukum Organisasi Perusahaan Dalam Sistem Hukum Indonesia", Asy-Syari'ah, Volume 17, Nomor 3, Desember 2015.

\section{Internet}

Fadlyna Ulfa Faisal, et. al., "Pelaksanaan Circular Resolution pada Perseroan Terbatas", dalam http://pasca.unhas.ac.id/jurnal/files/86802e6ad7e7c1fb.pdf, Akses 20 Juni 2020

\section{Peraturan Perundang-Undangan}

Kitab Undang-Undang Hukum Perdata

Undang-Undang Nomor 40 Tahun 2007 tentang Perseroan Terbatas

\section{Putusan}

PT. Duta Jakarta Sejahtera v. Djadjang Tanuwidjaja, Putusan Mahkamah Agung RI Nomor 1320K/PDT/2016 jo. Putusan Pengadilan Tinggi DKI Jakarta Nomor 493/PDT/2015/PT.DKI jo. Putusan Pengadilan Negeri Jakarta Selatan Nomor 193/Pdt.G/2014/PN.Jkt.Sel. 